\title{
The Influence of Climate Organization and Job Satisfaction for Turnover Intention through Work Stress of Employees Pt. American President Line Logistics (Distribution Center Cakung)
}

\author{
Masydzulhak Djamil ${ }^{1}$, Ahmad Hidayat Sutawijaya ${ }^{2}$, SigitAnditya Irawan ${ }^{3}$ \\ ${ }^{1}$ Profesor of Management Mercu Buana University Jakarta Indonesia \\ ${ }^{2}$ Ahmad H Sutawijaya Lecturer of Doctoral Management, Mercua Buana University Jakarta Indonesia \\ ${ }^{3}$ Sigit A Irawan Student of Management Mercu Buana University Jakarta Indonesia
}

*Corresponding Author: Masydzulhak Djamil, Profesor of Management Mercu Buana University Jakarta Indonesia

\begin{abstract}
This study aims to analyze the influence of organizational climate and job satisfaction on Turnover Intention through work stress. The fact that the high turnover rate of PT. APL Logistics DC Cakung in the Year 2013-2015. The research method used is path analysis with Partial Least Square (PLS) analysis tool. Respoden numbered 125 people. The results of this study indicate that (1) Organizational Climate has no significant effect on Turnover Intention, (2) Job Satisfaction has significant effect on Turnover Intention, (3) Working Stress significantly influence Turnover Intention, (4) Organizational Climate has significant influence to Turnover Intention through Job Stress, (5) Job Satisfaction has no significant effect on Turnover Intention through Job Stress, (6) There is no total influence of Organizational Climate on Turnover Intention through Job Stress, (7) There is total influence of Job Satisfaction on Turnover Intention through Job Stress .
\end{abstract}

Keywords: Job satisfaction, job stress, organizational climate, turnover intention, pathanalysis, partial least square( $P L S)$

\section{INTRODUCTION}

One of the problems in PT APL Logistics DC Cakung is increasing Turnover, so companies often lose their best talent. Data shows that there is a considerable increase of incoming and outgoing employees during 2013. In 2013 the percentage gained by $14,46 \%, 2014$ by $20.99 \%$ and by 2015 by $31.21 \%$. The high number of employee turnover intentions indicates a lack of company attention towards employees that can ultimately lead to a real intention to move for employees (Turnover Intention). According to Martin \& Michael J. Kaufman (2013) states that intent to quit is an early signal will an employee action to get out of the company.

Another indication can be seen based on the data of the exclusion of employees at work with a variety of reasons such as sick, absent without explanation, official permission, and special leave taken from the year 2016. According to Nelson (2008) states that the cause of absences that employees doing the work climate unsatisfactory, unsatisfied with work, employee conflicts that occur at work, unsuitable salaries and high levels of stress.

The phenomenon that occurs as many as 25 respondents stated that the Climate Employees organization is not as expected and by 10 respondents stated that the organizationsclimate is not predicted turnover intention. This result is supported by Suhanto (2009) that one of the factors that need to be the company's attention to reduce employee turnover is how companies manage the negative organizational climate in work activities as a result of the company's effective and efficiency.

The existence of the phenomenon of employees experiencing dissatisfaction at work, the results showed that 26 respondents stated that one of the influence of Turnover Intention is dissatisfaction about their job, and 9 respondents stated incorrectly with the statement of job satisfaction increased Turnover Intention of employees. This result is supported by Kim and Stoner (2013: 99) that the factors associated with the employee will stop from his job (turnover) is due to lack of satisfaction in his job or any other promising business. 
Given the level of dissatisfaction with the job, the employee is depressed and cause work stress, as many as 19 respondents stated that one of the influence of Turnover Intention increased due to work stress felt by employees and 16 respondents stated incorrectly with statement about stress Work is becoming an increasing impact of Turnover Intention employees. These results were confirmed by Hermitha (2011: 54) that one of the five types of consequences of the impact of stress on organizations such as absence, low productivity, increased turnover, job dissatisfaction and alienation office colleagues may lower the attachment and loyalty to the organization.

The phenomenon is also reinforced by the results of pre-research that states that as many as 21 respondents stated having intention to do Turnover and 14 respondents stated no intention to do Turnover. These results were confirmed Kumar et al, (2012: 9) which mengemukkakan that turnover is a serious problem in the field of human resource management related to high labor turnover. Based on the description of the phenomenon as described above, the authors explain the problem into research with the topic of Climate Influence Organization And Job Satisfaction of Turnover Intention Through Stress Work case study on employees of PT APL Logistics DC Cakung.

\subsection{Research Purposes}

- Knowing and analyzing Organizational Climate on Turnover Intention on employees of PT. APL Logistics in DC cakung.

- Knowing and analyzing Job Satisfaction on Turnover Intention on employees of PT. APL Logistics in DC cakung.

- Knowing and analyzing Job Stress on Turnover Intention on employees of PT. APL Logistics in DC cakung.

- Knowing and analyzing the Climate Organization there is indirect influence through Work Stress on Turnover Intention on employees of PT. APL Logistics in DC cakung.

- Knowing and analyzing Job Satisfaction is no indirect influence through Job Stress on employees to turnover intention PT. APL Logistics in DC cakung.

- Knowing and analyzing the total effect of Climate Organization on Turnover Intention through Job Stress on PT. APL Logistics in DC cakung.

- Analyzing and knowing the influence of total job satisfaction on Turnover Intention through Job Stress on PT. APL Logistics in DC cakung.

\section{LITERATURE REVIEW}

Wirawan (2008: 12), Organizational Climate is the perception of organizational members (individually and in groups) and those who are constantly in touch with organizations (eg suppliers, consumers, consultants and contractors) about what is or is happening in the internal environment of the organization on a regular basis, That affect the attitudes and behaviors of the organization and the performance of member organizations that then determine the performance of the organization.Luthans (2011) states that job satisfaction as a set of rules concerning pleasant and unpleasant feelings relates to their work.Karimi and Alipour (2011) stated that job stress can be described as the discomfort felt by individuals whose abilities and resources can not be overcome with demands, events and situations in their workplace.

Cooper (2009) that work stress is divided into five dimensions of work conditions, workload, time, physical hazards and job specialization. Kash and Naufal (2010) most employees who leave the company for voluntary reasons can be categorized for avoidable voluntary turnover and unavoidable voluntary turnover.

\subsection{Research Framework}

The problem discussed in this research which becomes the dependent variable is Turnover Intention (Y2). The dependent variable is influenced by two independent variables, namely Climate Organization as (X1) and Job Satisfaction as (X2). The existence of direct influence, indirect influence and total influence, Then Job Stress (Y1) role becomes intervening variable in this research. Job stress variable becomes an intervening for organizational climate and job satisfaction toward turnover intention. 


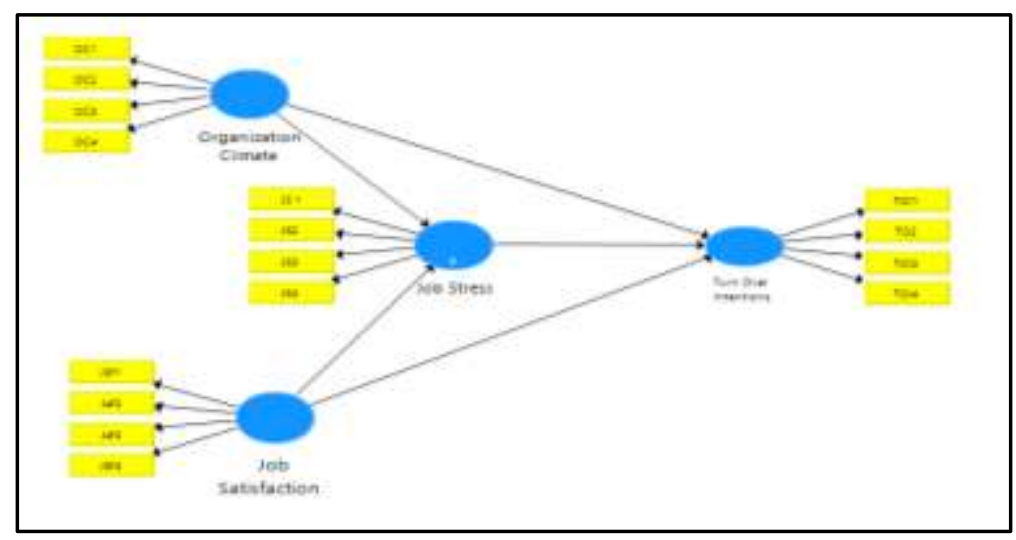

Figure1. Influence and Relationship of Independent and Dependent Variables

Based on the picture above, it is known that: (i) organizational climate has an effect on job stress (ii) Job satisfaction predicted work stress (iii) Climate organization directly influence to turnover intention (iv) job satisfaction predictedturnover intention (v) Work stress predicted turnover intention (vi) job stress mediating organizational climate to predicted turnover intention (vii) job stress mediating job satisfaction to predict turnover intention

\section{RESEARCH METHODS}

Ex post facto research design with type of Descriptive research to get a picture of the symptoms that occur that affect the variables (cause and effect) in the population. Data collection by Probility sampling by giving equal opportunity to the overall sampling that has been determined. The scope of the research is the employees of PT. APL Logistic Jakarta. The population number is 182 people using solvin model (Masydzulhak et al (2015) with 5\% confidence in respondent as much as 125 respondents This research uses path analysis originally developed by Wrigth and Niel (Masydzulhak et al 2015 ) Which analyzed the effect of lagsung and indirect and its total effect. Such in Path analysis tested the validity and reliability with exogenous variable and endogenous variable Analysis of this research using Partial Least Square (PLS)

\section{RESUlt AND Discussion}

\subsection{Outer Model Test}

Using the PLS method to measure the validity of the research, the results are shown in Table 1.

Table1. Factor Loadings

\begin{tabular}{|c|c|c|c|c|}
\hline & Organizational climate & Job statisfaction & Job stress & Turnover Intention \\
\hline IO2 & 0.899 & & & \\
\hline IO3 & 0.812 & & & \\
\hline IO4 & 0.842 & & & \\
\hline KK1 & & 0.717 & & \\
\hline KK2 & & 0.884 & & \\
\hline KK3 & & 0.817 & & \\
\hline KK4 & & 0.889 & & \\
\hline KK5 & & 0.832 & & \\
\hline SK1 & & & 0.641 & \\
\hline SK2 & & & 0.523 & \\
\hline SK3 & & & 0.588 & \\
\hline SK4 & & & 0.632 & \\
\hline SK5 & & & 0.722 & \\
\hline TI1 & & & & 0.802 \\
\hline T12 & & & & 0.831 \\
\hline T13 & & & & \\
\hline IO1 & & & & \\
\hline
\end{tabular}

The results of the analysis in Table 1 show that the organization's Climate variable, job satisfaction, work stress, intention turnover are valid according to AVE standard $=0.5$. 
The Influence of Climate Organization and Job Satisfaction for Turnover Intention through Work Stress of Employees Pt. American President Line Logistics (Distribution Center Cakung)

\subsection{Reliability Test}

We use two methods Test Reliability in PLS, the Cronbach's alpha and composite reliability. The following test results reliability research.

Table2. Reliability Test

\begin{tabular}{|l|c|c|c|c|}
\hline \multicolumn{1}{|c|}{ Variable } & Composite Reliability & Cronbach's Alpha & Criterion & Valid \\
\hline Organizational climate & 0,915 & 0,876 & \multirow{4}{*}{$\geq 0,70$} & Valid \\
\cline { 1 - 3 } \cline { 5 - 5 } & 0,917 & 0,886 & Valid \\
\hline Job satisfaction & 0,760 & 0,705 & & Valid \\
\hline Job stress & 0,875 & 0,787 & & Valid \\
\hline Turnover Intention & & &
\end{tabular}

Source: PLS Output Version 3, Data Processed

Reliability test results showed that there is no significant difference between Composite reliability with Cronbach's Alpha, this results show that the scale of measurement is credible and strong.

\subsection{Determinant Coefficient (R2)}

The Coefficient of Determination (R2) test result is shown in the following Table

Table3. Determinant Coefficient $\left(R^{2}\right)$

\begin{tabular}{|c|c|}
\hline Endogen Variables & $\mathbf{R}^{2}$ \\
\hline Job Stress & 0,124 \\
\hline Turnover Intention & 0,378 \\
\hline
\end{tabular}

R-Square Value for Work Stress of 0.124 which illustrates that the organizational climate and job satisfaction affect work stress of $12.4 \%$ this indicates that the organizational climate and job satisfaction affect but not too strong. For variable Turnover Intention influence of organizational climate variable and job satisfaction and work stress influence to Turnover Intention variable equal to 0,378 or $37,8 \%$. Means the model has a goodness fit good model level.

Furthermore, other variables affect the stress of work in Kim \& Stoner's research, (2013) that job satisfaction affects work stress and causes the employee's desire to get out. Significant influence of organizational climate, job satisfaction and job stress can affect employees' desire to do the turnover. In accordance with the results of research Klassen, Robert M. (2011) states that job stress affect the turnover intention (desire to exit).

\subsection{Hypothesis Test}

Hypothesis test in this research to test direct influence between variable can be seen in picture and table 4 below.

Table4. Significant Test (Direct Effect)

\begin{tabular}{|c|c|c|c|c|}
\hline & \begin{tabular}{|l|} 
Original \\
Sample (O)
\end{tabular} & $\begin{array}{|ll|}\begin{array}{l}\text { Standard } \\
\text { (STDEV) }\end{array} & \text { Deviation } \\
\end{array}$ & $\begin{array}{|lr|} & \text { Statistics } \\
(|\mathrm{O} / \mathrm{STDEV}|)\end{array}$ & P Values \\
\hline Organizational Climate -> Job Stress & 0.351 & 0.108 & 3.262 & 0.001 \\
\hline Organizational Climate-> Turnover Intention & -0.117 & 0.081 & 1.443 & 0.150 \\
\hline Job Satisfaction -> Job Stress & 0.008 & 0.190 & 0.041 & 0.967 \\
\hline Job Satisfaction -> Turnover Intention & 0.211 & 0.095 & 2.231 & 0.026 \\
\hline Job Stress -> Turnover Intention & 0.600 & 0.146 & 4.100 & 0.000 \\
\hline
\end{tabular}

Source: PLS Output Version 3, Data Processed

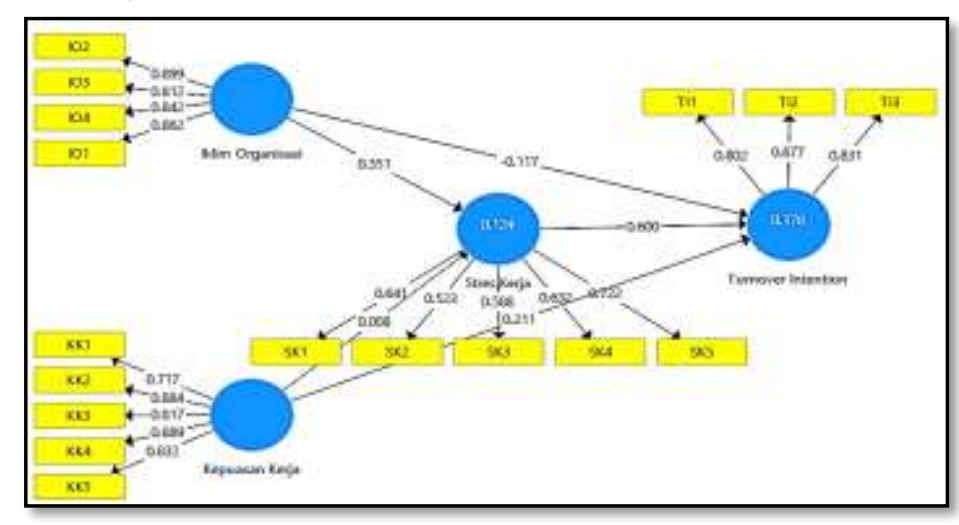

Figure2. Path Coefficients 
Based on Table 3, and figure 2 above the results of the analysis of inter-mediation variables that have been tested with the level of confidence $\mathrm{P}$ (value) $=5 \%$ with the number of samples of 125 respondents then obtained: $125-2=123$ respondents $t$ table $=1.96$ then it can Described as follows:

- H1: supported, there are organizational climate influences with work stress (see table 3 and figure 2) factors of organizational climate can predicted employee stress level.

- H2: not supported, climate organization has no effect on turnover intention. This is in line with research Oktem, et al (2016).

- H3: not supported, Job satisfaction has no effect on job stress (table 3) above. In line with the results of Aziri research, Brikend, (2011).

- H4: suppoerted, job satisfaction has an effect on turnover intention. job satisfaction variable to turnover intention variable is positive that is equal to 0,211. In accordance with research conducted Khan and Muhammad (2014).

- H5: suppoerted, job stress variables influence on turnover intention this is in line with research conducted by Kafashpoor, et al (2014).

The results of the analysis that the $\mathrm{H} 2$ and $\mathrm{H} 3$ is rejected then the researchers examined by intervening (see table 4).

Table5. Significant test (Indirect Effect)

\begin{tabular}{|l|l|l|l|l|}
\hline & $\begin{array}{l}\text { Original } \\
\text { Sample (O) }\end{array}$ & $\begin{array}{l}\text { Standard Deviation } \\
(\text { STDEV) }\end{array}$ & $\begin{array}{l}\text { T Statistics } \\
(\mid \mathbf{O} / \text { STDEV })\end{array}$ & Palues \\
\hline Organizational Climate -> Job Stress & & & & \\
\hline Organizational Climate-> Turnover Intention & 0.210 & 0.070 & 3.014 & 0.003 \\
\hline Job Satisfaction -> Job Stress & & & & \\
\hline Job Satisfaction -> Turnover Intention & 0.005 & 0.107 & 0.043 & 0.965 \\
\hline Job Stress -> Turnover Intention & & & & \\
\hline
\end{tabular}

Source: PLS Output Version 3, Data Processed

- H6: supported, organizational climate indirectly affects turnover intention through Job Stress it can be concluded that the organizational climate has a significant effect on turnover intention through job stress. In accordance with research conducted by Oktem, et al (2016) that work stress is a factor affecting job satisfaction on turnover intention.

- H7: not supported, job satisfaction directly no effect on turnover intention through stress. In line with previous research by Wang and Xiang (2011) that job stress is not an intervening of the effect of job satisfaction on turnover intention. The result of indirect effect analysis from path analysis illustrates that $\mathrm{H} 7$ (organizational climate variable to turnover intention through work stress) is not supported then the authors analyze the total effect. The results of the total effect hypothesis test are shown in table 6 below.

Table6. Significant test (Total Effect)

\begin{tabular}{|c|c|c|c|c|}
\hline & $\begin{array}{c}\text { Original } \\
\text { Sample (O) }\end{array}$ & $\begin{array}{c}\text { Standard Deviation } \\
\text { (STDEV) }\end{array}$ & $\begin{array}{c}\text { T Statistics } \\
(\mid \mathrm{O} / \text { STDEV })\end{array}$ & $\begin{array}{c}\mathrm{P} \\
\text { Values }\end{array}$ \\
\hline Organizational Climate -> Job Stress & 0.351 & 0.108 & 3.262 & 0.001 \\
\hline Organizational Climate-> Turnover Intention & 0.093 & 0.086 & 1.075 & 0.283 \\
\hline Job Satisfaction -> Job Stress & 0.008 & 0.190 & 0.041 & 0.967 \\
\hline Job Satisfaction -> Turnover Intention & 0.216 & 0.091 & 2.376 & 0.018 \\
\hline Job Stress -> Turnover Intention & 0.600 & 0.146 & 4.100 & 0.000 \\
\hline
\end{tabular}

Source: PLS Output Version 3, Data Processed

- H6: not supported, there is no influence of organizational climate total direct on turnover intention with job stress. The research results are in line with previous research conducted by Jyoti (2013) that there is no total climate influence of organization to turnover intention through job stress. 
- H7: supported,there is a totaldirect effect of job satisfaction on turnover intention through job stress. Thus, $\mathrm{H} 7$ hypothesis in this research is supported. In conclusion, there is total influence of job satisfaction on turnover intention through job stress. The results are in line with previous research conducted by Adebayo (2011) that there is a total influence of job satisfaction on turnover intention through job stress.

\section{CONCLUSION AND RECOMMENDATIONS}

Based on the results of the analysis and the above description can be concluded this research as follows:

- Climate organization significantly affect the work stress if the organization's climate does not support within the company environment will increase job stress

- Organizational climate has no effect on turnover intention for intervening variable

- Job satisfaction does not affect the stress of work, to be able to affect intervening variable required so that there is a significant effect of job satisfaction on job stress

- Job Satisfaction proved to have a significant effect on turnover intention. It shows that job satisfaction directly affect turnover intention.

- Job stress proved to have a significant effect on turnover intention. This is because the value of $t$ statistics of $4.100 \geq 1.96$.

- Organizational Climate proved to have a significant effect on turnover intention through job stress.

- Job Satisfaction proved to have a significant effect on turnover intention through job stress.

\section{REFERENCES}

[1] Adebayo, SulaimanOlanrewaju. 2011. "Influence of Supervisory Behaviour and Job Stress on Job Satisfaction and Turnover Intention pf Police Personnel in Ekiti State". Journal of Management and Strategy. Vol. 2 No. 3, Page. 13-20.

[2] Aziri, Brikend, 2011. "Job Satisfaction : A Literature Review". Journal of Management Research and Practice.Vol. 03.No.04. Desember 2011.Hal.77-86.

[3] Cooper, D. R. \& Schindler, P. S. 2009. Business Research Methods. 8th Edition, Singapore: McGraw-Hill. Co, pp:108-115.

[4] Ghozali, Imam.. 2008. Structural Equation Modeling. Metode Partial Least Square (PLS). Semarang: Penerbit Universitas Diponegoro.

[5] Hermitha. 2011. Pengaruh Stres kerja terhadap Kinerja Karyawan Pada PT. Semen Tonasa (PERSERO) pangkep. Skripsi. Makasar: Universitas Hasanudin

[6] Jyoti, Jeevan. 2013. "Impact of Organizational Climate on Job Satisfaction, Job Commitment and Intention to Leave: An Empirical Model". Journal of Business Theory and Practice. Vol. 1 No. 1, Page. 66-82.

[7] Kafashpoor, Azar., SamanehSadeghian., Neda Shakori., and Sara Kavoosi. 2014. The Impact of Job Stress on Turnover Intention Mediating Role of Job Satisfaction and Affective Commitment". Applied Mathematics in Engineering, Management and Technology. Vol. 2 No. 1, Page. 96-102.

[8] Khan, Alamdar Hussain and Mauhammad Aleem. 2014. "Impact of job Satisfaction on Employee Turnover: An Empirical Study of Autonomous Medical Institutions of Pakistan”. Journal of International Studies. Vol. 7 No. 1, Page. 122-132.

[9] Kash, B. A., Naufal, G. S., Cortés, L., \& Johnson, C. E. 2010. Exploring factors associated with turnover among registered nurse (RN) supervisors in nursing homes.Journal of Applied Gerontology, No.29, pp. 107-127.

[10] Kim dan Stoner. 2013 dalam "Turnover Happens Once The Worker Detaches From Employment“. Hal 99103.

[11] Klassen, Robert M. 2011. The Occupationally Commitmen't and Intentioned to Quit Of Praticing and Pre-service Teachers: Influence of Self-Efficacy, Job stres, and Teaching Context. Contemporary Educational Psychology. No. 36 (2), pp: 114-129.

[12] Karimi, Roohangiz and Farhad Alipour. 2011. Reduce Job stress in Organizations: Role of Locus of Control, International Journal of Business and Social Science. Vol. 2 No. 18. pp 130 - 143. 
[13] Kumar, \& Yacob. 2012. A Study on Turnover Intentioned in Fast Food Industry: Empoyees' Fit to The Organizational Culture and the Important of their Commitment.International Journal of Academic Research in Business and Social Sciences. 2 (5), pp:9-42.

[14] Luthans, F. 2011. Organizational behavior (12th ed.). New York: McGraw-Hill, Inc. hal. 120.

[15] Martin, Michael J. Kaufman, Eric K. 2013. "Do Job Satisfaction and Commitment to the Organization Matter When It Comes to Retaining Employees". Journal of Extention, Volume 51 No:4.

[16] Djamil Masydzulhak, Ahmad sutawijaya, EdyNugroho.2015. MemahamiPenulisanIlmiahdan Metode penelitian. Bogor. LP2S.

[17] Nelson.008.Penyebab-Penyebab Absensi Karyawan: hhtp://kumpulanistilah.com.

[18] Oktem, Sukran., Burcak Kiziltan., and Menekse Oztoprak. 2016. "The Effect of Organizational Climate and Organizational Trust on Organizational Identification, Jobsatisfaction and Intention of Turnover: An Application in Hotel Management”. Journal of Business Research Turk. Vol. 8 No. 4.

[19] Suhanto, E. 2009, Pengaruh Stress Kerja dan Iklim Organisasi terhadap Turnover Intention dengan Kepuasan Kerja sebagai Variabel Intervening. Studi di BII, Universitas Diponegoro. Hal. 13-14.

[20] Wang, Shuhong and Xiang Yi. 2011. "It's Happiness That Counts: Full Mediating Effect of Job Satisfaction on The Linkage From LMX to Turnover Intention in Chinese Companies". International Journal of Leadership Studies. Vol. 6 Issue. 3, Page 337-356.

[21] Wirawan. 2008. Budaya dan Iklim Organisasi : Teori Aplikasi dan Penelitian. Jakarta: Salemba Empat.

\section{AUTHORS' BIOGRAPHY}

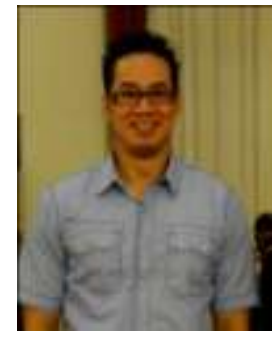

Achmad H Sutawidjaya obtained his Doctor of Business Administrations (DBA) from San Beda College, Business School, and Manila, Philippines in 2008. The Master of Commerce (M.Com) degree was obtained at the University of Wollongong, Australia in 1997. The Author, got master of Philosophy (M.Phil) at Maastricht School of Management (MSM), Netherland. He, Experience as a professional for 13 years, at BTPN Bank, Hastin Bank, PT.SNN, and PT. NUArt. In 2009, decided full carrier as an academician at Bakrie University. There, he was a Member of Senate of Bakrie University, Head of Technical Implementation Unit of UBPreneur, Head of Technical Implementer Unit of Community Service of teachers in Master of Management Program. In 2013, Suta joins Mercu Buana University. In addition to being a lecturer in "Operations Strategic and Process Management", "Entrepreneurship", "Strategic Management" and "Quality Management", he became CEO of PT APJ Consultant engaged in telecommunication, outsourcing, HR development and Assessment Center (2013 - present), CEO of CV DIAMOND Wedding Organizer (1990-present). Various researches and scientific journals have been published, either in the University of Mercu Buana or in several universities in Indonesia and abroad, especially in the field of operations management. Several titles of his published works include: Entrepreneurship Management: Concepts (UB Press, 2012), Operations Strategic Process and Management (Press Center 2015) and Entrepreneurship Management: Concepts and Cases (Press Releases, 2015), research methodology (2016), process strategy operations (2016) and Supply Chain Management (2017).

Citation: Masydzulhak Djamil, Ahmad Hidayat Sutawijaya, SigitAnditya Irawan. " The Influence of Climate Organization and Job Satisfaction for Turnover Intention through Work Stress of Employees Pt. American President Line Logistics (Distribution Center Cakung)" International Journal of Managerial Studies and Research (IJMSR), vol 6, no. 1, 2018, pp. 42-48. doi:http://dx.doi.org/10.20431/2349-0349.0601006.

Copyright: () 2018 Authors. This is an open-access article distributed under the terms of the Creative Commons Attribution License, which permits unrestricted use, distribution, and reproduction in any medium, provided the original author and source are credited. 